$\begin{array}{r}\text { Volume and Issues Obtainable at Center for Sustainability Research and Consultancy } \\ \text { Journal of Business and Social Review in Emerging Economies } \\ \text { ISSN: 2519-089X (E): 2519-0326 } \\ \text { Volume 6: No. 4, December 2020 } \\ \text { CSRC } \\ \text { Journal homepage: www.publishing.globalcsrc.org/jbsee } \\ \hline\end{array}$

\title{
Service Quality and Customer Retention in Malaysian Commercial Banks
}

\begin{tabular}{|c|c|}
\hline 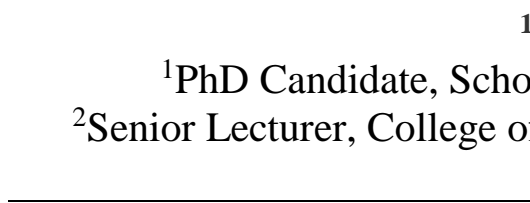 & $\begin{array}{l}\text { n Weng Kong, }{ }^{2} \text { Maria Abdul Rahman } \\
\text { Business, Universiti Utara Malaysia, } 69 \text {.wkchim@ gmail.com } \\
\text { iness, School of Business Management, Universiti Utara Malaysia, } \\
\text { maria@ uum.edu.my }\end{array}$ \\
\hline ARTICLE DETAILS & \multirow{4}{*}{$\begin{array}{l}\text { ABSTRACT } \\
\text { This conceptual paper explores the contribution of service quality on } \\
\text { banks' customer retention. Customer is the core factors to any } \\
\text { business industry and there is no exception for the banking industry. } \\
\text { Customers will only retain with the same bank provided there is a } \\
\text { quality service. Service comes in the form of how the bank's } \\
\text { employee treats the customers and from physical facilities and other } \\
\text { tangibles used in banking transactions. Contribution of service quality } \\
\text { is indefinite and without it, firm's business will lose out to other } \\
\text { banks. Banks not only compete with other banks but banks' branches } \\
\text { as well. The importance of the banking business cannot be neglected } \\
\text { as it has contributed to Malaysia Gross Domestic Products in term of } \\
\text { service industry. Service is not similar with goods or physical } \\
\text { products as it is intangible and only can be experienced during the } \\
\text { process of selling or buying. Good quality service must be prioritized } \\
\text { in helping retaining customers even with the Industrial Revolution } 4.0 \\
\text { where it is "a mechanism that is controlled or monitored by computer- } \\
\text { based". Contribution of human capital which is cannot be separated in } \\
\text { term of knowledge, friendly approach and ethical help in delivering } \\
\text { quality service. One of the methods can be applied by the bank is the } \\
\text { commitment of monitoring and servicing customer requirements to } \\
\text { deliver high levels of service quality for total customer satisfaction. }\end{array}$} \\
\hline $\begin{array}{l}\text { History } \\
\text { Revised format: November } \\
2020 \\
\text { Available Online: December } \\
2020\end{array}$ & \\
\hline $\begin{array}{l}\text { Keywords } \\
\text { Service quality, Customer } \\
\text { Retention, Satisfaction, Banks }\end{array}$ & \\
\hline $\begin{array}{l}\text { JEL Classification } \\
M 10, M 14\end{array}$ & \\
\hline
\end{tabular}

OPEN ACCESS

(C) 2020 Center for Sustainability Research and Consultancy Pakistan under a Creative Commons Attribution-NonCommercial-ShareAlike 4.0

Corresponding author's email address: $\underline{69 . w k c h i m @ g m a i l . c o m}$

Recommended citation: Kong, C. W. \& Rahman, M. A. (2020). Service Quality and Customer Retention in Malaysian Commercial Banks. Journal of Business and Social Review in Emerging Economies, 6(4), 1303-1312

\section{Introduction}

For businesses, focusing on customers have a tangible benefit. Customers are the sources of revenue to the company to meet the bottom line. Moreover, if the company is able to retain the customers, the continuous stream of revenue can be generated. Looking back to 1990s, Dawkins and Reichheld highlighted the distinct of customer retention into one of the reputable marketing strategies. According to these authors customer retention strategies can be used not only banking but in a wide range of industries. Customer retention should be emphasized by the banking industry since bringing in new customers cost five times more compare to the cost of retained customers. According to Noel Yee, Tracy 
Yun and Jackie Yau (2013) customer retention owing from the aggregate of satisfaction during the purchase process and company should keep on improving customer satisfaction. Only one out of twentyfive unsatisfied customers will express the dissatisfaction and happy customers will tell four to five customers about the satisfaction, but unsatisfied customers will tell nine to twelve customers about the unsatisfactory experiences (Hundre, Raj Kumar, and Dileep Kumar, 2013).

Mecha, Martin, and Ondieki (2015) the long-term effect of customer retention is on the customer value and firms capitalized on this phenomenon as it brings the firm profits. In the annual financial reports of Malaysia's individual bank, profitability of the banks has been fluctuating for the past decade (appendix A). The effect of the bank's mergers has automatically created an enlarged customer based where revenue should be increased or improved. As mentioned by Lai, Ling, Eng, Cheng, and Ting (2015), the merged bank has benefited from the increased economies of scale and therefore reduce its operation cost. Subsequently the merged bank is able to take in more profit and hence increase shareholders' wealth. Regrettably, profit of some banks remains constant or even decreased as compared to the preceding year.

Aik, Hassan, Hassan, and Mohamed (2015) the conclusions of the study on merger exercise is the operating performance improve significantly after the merger compared to before the merger. Furthermore, from the preceding studies, the running cost to attract new customers is five to ten times more compared to maintaining an existing customer (Hundre et al., 2013; Mecha et al., 2015). Notwithstanding the outcome, banks should look beyond retaining customers, but also the need of attracting new ones to replace customers that left. With this, it will maximize the profits while minimizing the operating cost.

Arokiasamy (2013) put forward that service quality proves the firm's ability to fulfil customers' demand and want. Organization must improvise service rendered in order to meet customers' demand since it is the vital point to compete in the market. On the other hand, Appannan, Doraisamy, and Hui (2013) state that banks are lagging in several areas, which include delay in answering customer calls, queuing time, how an employee greets the customers, whether information received by customers was accurate and adequate, and any follow-up by the bank's employee. Some banks even outsourced their service quality survey to other professional companies while some are carried out itself to determine where the bank service quality stands.

Banks are competing intensely in this highly competitive environment to offer quality-oriented services according to customers' expectations. Determining the level of service quality allows banks to understand customers' needs and wants. Offering excellent quality service to customers nowadays in the business environment is crucial due to the intense competition. The add-ons of the advantages of quality service will boost the company's image, enhance customer retention, attracting potential customers through word-of-mouth and in the long run increase the company profit (Osman and Sentosa, 2014).

According to Appannan et al., (2013), service quality is important to satisfy customers theoretically and, or empirically. This has been proven in various industries that comprise of service industries. In the banking industry, products are homogeneous and the only way for banks to differentiate is through outstanding service quality that satisfy the customers and leave an impression. They note that service quality is a vital factor to influence customers' satisfaction level in banking. Quality in banking is a multi-variable concept which consists of convenience reliability, service portfolio and most importantly the employee delivering the service.

Service quality starts with relationship establishment before any delivering of business transaction. As mentioned by Al-Alak (2014) research, as the quality of relationship increases between the service provider and customers, it will have a significant influence on the customer's behaviour in terms of continuity of the relationship and word-of-mouth promotion. Lau, Cheung, Lam, and Chu (2013) 
globalization has changed customer behaviour about banking industry and the way of running the banking operation has become more dynamic and competitive. They highlight the introduction of new methods of delivering services such as automated teller machines (ATM), phone and internet banking. Alnsour (2013) the changes of recent environmental factors like the unexpected increase of competition and the changing of customers' perspective, make marketing strategies change from "offensive marketing", getting new customers as priority to "defensive marketing", which concentrate on customer retention.

Customer satisfaction has been treated as a critical factor on holding customers in a long-term duration in relationship marketing literature. Thus, in any service failure encountered by a customer, the most important step to undertake is to restore the customer's satisfaction (Siu, Zhang and Yau, 2013). Therefore, this conceptual paper will touch on the importance of service quality to be delivered in order to meet customers' satisfaction that can help banks to retain their existing customers and prevent these customers from being attracted by competitors.

\section{Literature Review}

The cost of customer acquisition is much higher than customer retention and a small increase in retention rates could drive large profit increases (Chang and Zhang, 2016). As mentioned earlier, customer retention is a critical factor in achieving customer satisfaction (Alnsour, 2013). These statements are strong enough to describe the importance of customer retention to any firm. To these previous researches, customer retention plays a significant role not only in the banking industry but others as well, in terms of meeting the bottom line. For bank's sustainability and performance improvement purposes, banks require the contribution of repeat purchase from customers that generate revenue. Thus, customer retention continues to be the dominant factor that allow any firm to be competitive in the business industry.

Banking business has been confronted by issues in customer retention due to establishment of banks branches, introduction of new service delivery, changes of customers' need and the banking environment as whole. Mecha et al. (2015) customers are moving from one bank to another looking for one bank that fit their needs. It is a challenge for the manager to build close relationships to retain existing customers who are at the same time, being lured by other banks. Once the competitors are able to build a close relationship with the customers, the chances of getting back the customers will be low. Hence, customer retention has been one of the goals of relationship marketing where initial contact rely on the relationship to be continued.

Hettiarachchy, and Samarasinghe (2016) define customer retention as "the longevity of a client's relationship with a product and/or service providing firm". Once there is an establishment of relationship between bank and customers, banks' employees are able to market additional products with quality service to retain the customers. Service quality must be felt by customers the moment they step into the banks and business transactions need relationship to be continued.

Relationship building champion the use of interaction between the service provider and customer through face-to-face communication. Added in with quality service, chances of competitors attracting firm's existing customers will be minimized. Tan, Hamid, and Chew (2016) banks that able to provide quality service have the advantages in marketing activities since improved service quality lead to the increase of revenue, opportunity of cross-sell, expanded market share and lastly higher customer retention rates. Banks acknowledge that they must compete in a more efficient way through the satisfying service quality. Syaqirah, and Faizurrahman (2014) conducted a research on hotel's room service quality using three stars hotels in Malaysia. They concluded that service quality is important as delivering exceptional service will bring customers a higher satisfaction, which denote the element of customer retention and thereafter increase the firm's profit. Similar with the banking industry, where customers must experience its services during the purchase process, then they can judge the service. 
There are numerous past researches on customer retention or on customer loyalty that examine different types of variables that contribute to customer retention in various service business industry, which include banking (e.g. Siu et al., 2013; Arokiasamy, 2013; Zeyad, and Wahab, 2013; Wang, Hsu, and Chih, 2014; Syaqirah, and Faizurrahman, 2014; Kandampully, et al., 2015; Mecha et al., 2015; Osman and Sentosa, 2016). Some of the exploration on customer retention include research on multichannel of service delivery, service failure recovery, service quality and impact of satisfaction to customers. According to these researches, banks are interested on providing new technology associated with service quality, rather than traditional delivery functions. The introduction of technology has changed retail banking significantly with the development of new ranges of products and improvement of delivery channels.

The contribution of service quality attracts many researchers due to its influence on the business industry since decades ago. Parasuraman, Berry, and Zeithaml, 1991 study (as cited in Bose and Gupta, 2013) proposed SERVQUAL as a measurement that evaluate the actual service quality rendered by service provider to the expected service quality by customers. According to the study, there are five dimensions to measure service quality foreseen by the customers. They also state the dimensions are related to three additional Ps of service marketing mix which include people, physical evidence, and process. Another fact pointed by them is "a general tenet in marketing and business holds that high-quality goods and services are favoured in the market". High quality performance produces assessable benefits in terms of profit, cost savings, and market share.

SERVQUAL is a multiple-item instrument with five dimensions: tangible, reliability, responsiveness, assurance, and empathy. Physical facilities, equipment and appearance of personnel are classified as tangibles and the remaining dimensions are classified under customer-based performance measure. It is more on the human interaction that bank employee provides to the customers. They define service quality as the difference between customer's expectations for the performance of a service before the service is endured and their perception on the service received. Intangible services are the most difficult to be evaluated due to customers' various perception and satisfaction levels. A quality service accepted by one customer may not be perceived as good quality by another.

Khan and Fasih, (2014) research examine satisfaction and loyalty through service quality in the banking industry by applying only 4 dimensions of tangible, reliability, assurance, and empathy which exclude responsiveness. The research conclusion is that service quality and all the dimensions tested have a significant and positive linkage to customer satisfaction and loyalty. Their findings also state that service is a non-stop process interaction between service providers and customers in an intangible activity which arrange "premium solutions" to customers that include physical and financial resources. In fact, banks are providing physical services such as ATM for deposits and withdrawal and the convenience of brick and mortar services in rural areas or for customers who are not familiar with technology. Generally, the usefulness of ATM is it can be used by customers from different banks.

Osman and Sentosa (2014) research on the understanding of mediating effect of customer satisfaction on service quality and loyalty relationship in Malaysia commercial banks. The results showed that service quality enhances customer satisfaction in Malaysian commercial banking industry, which all the hypotheses testing was supported. The results translate into the relationship between customer satisfaction and profitability and is linked to customers' satisfaction that influences customer loyalty. The research conclude that satisfied customers will make repeat purchases and a small percentage of customers will leave for the competitor.

Kandampully et al. (2015) define loyalty as attitudinal loyalty where it is the commitment of customers to perform any repeat purchase or visitation to the same providers in the future for chosen products or services, although there are influences from others. The definition is similar with the definition of customer retention where customers establish a continuous relationship with a product or service 
provider. Therefore, for this conceptual study it does not attempt to differentiate the two definitions.

It is of paramount importance to treat customer retention as the primary marketing strategy for the bank. Past literatures have supported that service quality indeed help the bank's performance, but it is not responding or aligning with the increase of customer base due to the bank's mergers. The inconsistence of bank's performance if not due to service quality, it may possible due to other factors such as demography of customers especially in term of customer's income.

\section{Customer Retention}

Edward and Sahadev (2013) the cost on capturing new customers is higher compare to the lower cost of retained customers which helps the profit of the firm. For service-oriented businesses like banking, a customer retention program is recommended due to the cross-sell opportunities and stream of revenue. One of the definitions by Hundre, Kumar, and Kumar (2013) customer retention is providing or meeting what customers want and as expected by them. Banks help customers meet their financial objective whether in term of investment or getting a loan. The banks need to exceed customers' expectations in order to convert them into devoted loyalists to the banks.

Kandampully et al. (2015) generating and sustaining customers to be retained in the firms assists in creating long-term and mutually beneficial relationship. They also highlight that retained customers will not be easily attracted by competitors which display a firm commitment by customers. Customers agreeable to the higher price show great purchasing intention and unwillingness to switch to competitors. Thus, retained customers can produce continuous high revenue that help banks meet the bottom line. However, banks must acknowledge that customers' expectations on service quality grow higher as the years pass.

There are several advantages when firms are applying customer retention in terms of economic benefits such as the customers' tenure with the firm is longer, repeated purchases due to a longer tenure, and most of all is the referral by these retained customers (Coussement, 2014). Customers providing referrals through positive word-of-mouth are much stronger than banks' self-promotions. However, if customers promote negative word-of-mouth, the impact is substantial. Therefore, the more customers and firms understand each other, it will result in the maintenance costs of their relationship to fall and hence, pushing up the net present value of retained customers. Accordingly, Mecha et al. (2015) pointed out that banks should intensify the customer retention strategies with more effective methods such as customer service and produce innovative products that are unlike the rest of the competitors.

From the past literatures on customer retention, it may describe that a low customer retention scenario is like "continue supplying oxygen to leaked tyre". The goal will never be reached, and it will cause the bank's operation cost to remain high which affect the bank's profit. Hundre, et al. (2013) for a company with a small customers base, losing a few customers is tantamount to crippling the company. Banks with a huge customer base does not translate to the bank being about to make more profits if the bank's customers continue to leave for their competitors because of the lack of consistent service quality from the bank's employees.

Bank's employees do not just sell the product, but they also develop relationships with the customers and educate them. Only then will the customers feel the service quality difference between the bank and its competitors. Banks that employ customer retention strategies often find it an efficient process due to the long-term relationship where customers already have the indication of interest on the products. Some customers may already have the impulse to buy and with a little force, the sales can be concluded. It is easier for the customers to make decision when they already capitalize on their purchase and service quality experience with the banks. Plus, Mecha et al. (2015) state firms need to distinguish its products to make competitors irrelevant and by carrying out such a move, sales will be increased and certainly survive in the market. Hence, it is important that banks treat customer retention as a sustainable business 
model which is in the arsenal for sustainable growth.

Customer retention is not only about the service products (Hundre et al., 2013) and they strongly feel that it is about how servicing existing customers and the way a reputation is created within and across the market-place. Additionally, customers expect to be treated on a more personalized or individualistic basis, given the demographic background and household income. Banks should not sell the products but the features instead.

Mecha et al. (2015) opine that service to the customers is one of the certain methods to apply customer retention. They explain to understand the customers and their needs with outstanding service is what they require where customers feel it is worth of the continuous relationship. Therefore, when customers have full confidence on the firm, their purchase intentions will be surged (Wang, Hsu, and Chih, 2014).

\section{Service Quality}

If customer satisfaction is the main reason of customer retention, banks should portray its products or service quality the moment a consumer walks into the bank's premise. The first contact is critical to the consumer before they turn into customers. Siu et al. (2013) customer satisfaction is an accumulation over certain number of meeting experiences and the firm shall continue to improve customer satisfaction through service quality for customer retention. For that reason, service quality has become one of the major researches by academics to explore.

Definition of service quality defined by Paul, Mittal, and Srivastav (2016) is the differences of actual service performance received and customer's expected service performance prior to the service. There is a positive effect on the performance of profit for the firm that lead to the competitive advantages due to the improved service quality. To enhance better service quality whether in term of employees' service or technology, banks have introduced more technology to customers. Technology has significantly facilitated the creation of new service products like ATMs. Setting-up self-service terminals at one corner in the branch for 24-hours banking transactions are some of the enhanced banking facilities. Banks need to monitor these technologies equipment to avoid any break-downs that affect service quality. All these introductions have provided new methods of how banks deliver services to customers. Nevertheless, in internet banking services there is a "chat" function where customers can communicate online with bank's employee. The traditional service that require human involvement is still needed, where financial matters are concerned.

Service quality is one of the crucial elements in building the success and becoming one of the rivals of any business organization. Osman and Sentosa (2016) banking business can be differentiated from the competitors by offering better service quality to the customers. And service quality is one of the reasons that will decide the success in the banking business. As defined by Osman and Sentosa (2016) service quality is an act or execution which make customers to receive the benefit. Banks must aware that it needs to portray different approaches when employees sells service products to customers.

The factor of service quality is where customer can feel the satisfaction and marketing textbooks have encouraged marketers to utilize this element to differentiate itself from the competitors and the competing brand (Appannan et al., 2013). It is impossible for the banks to be differentiated as every bank has homogeneous products. Hence, it is the bank's management responsibility to differentiate itself or among the bank's branches through service quality. Service quality is one of the critical substances that affect customers' satisfaction level in the banking industry and providing service is not only from the front office employees or sales team but from the operation employees up to the manager. Each employee represents the company and should provide the best of quality service to customers.

To draw the attention and thereafter retain the customers, service quality is one of the crucial elements (Islam, Ahmed, and Razak, 2015). The research conducted by them is in Malaysia Islamic banking, 
service quality has been treated as a sensible requirement in this stiff banking competition and for the expansion of market share and profit, banks need to produce superior service quality. Lau et al. (2013) banks are spending more time on service quality for the purpose of getting competitive advantage in term of increasing revenue and customer retention or loyalty from the customers. Furthermore, service quality expected by customers is rising due to the easily available of information in terms of advertisement from any banks and this allow customers to compare. And Khan and Fasih (2014) research has stated that researchers from all over the world maintain that by providing quality service will lead to strengthening the competitive advantage to any business industry.

Service quality is a continuous effort and all employees should have the commitment to do the same. Lau et al. (2013) normally customers purchase from firm due to the service provided and being assured for certain privileges. Providing quality service is not only for short term periods but for future purchases as well. Khan and Fasih (2014) the competence of a firm to foresee the future needs of customers represents the service quality and this will enhance the satisfaction of customers and the retention rate of the firm. Paul et al. (2016) explains that if customers are satisfied with the service, it shows in their mental state, where customers make a comparison of their purchase expectation prior to the purchase with the actual perception on after the purchase process.

Osman, Mohamad, and Mohamad (2016) there are many past researches on banking industry such as Greece, India, China, Taiwan and Iran which indicate that service quality plays a great influence and one of the important roles that make customers loyal to the bank. Despite that, research by Sheng-Qiang and Xue-Mei (2010) (as cited by Osman et al., 2016) state that tangible in service quality dimension has no significant impact on loyalty. Therefore, researchers must be aware that different countries have different cultures.

\section{Conclusion and Recommendation}

Chang, and Zhang (2016) there are various studies that proved that a small increase of customer retention created a large increase on profits. It has been proven from the past researches, customer retention is indeed the main element for business industry to perform or can be sustained provided there is some infrastructure that helps. With customer retention, banks revenue will be increased due to the repeat purchase and this in turn increase the profit for the bank. Moreover, retained customers help in providing free word-of-mouth referral to attract new customers. Words from satisfied customers carry more weight compared to the influences activated by the employees of the firm.

Mergers between the banks have enlarged their customer base. With fewer banks in the market, competition is expected to lessen but it still exists, just that it has shifted from between banks to between branches. However, there is the possibility of customers shift to another bank due to other reasons. Hettiarachchy and Samarasinghe (2016) "a firm with effective customer retention have the capability to convinces their clients to stay with the firm". Customer retention definition given by Syaqirah, and Faizurrahman (2014) is customers willingness to remain with the same service provider. Banks must utilize any marketing gimmicks and strategy as well as utilizing the manpower of the employees to retain any existing customers due to the advantages of customer retention are so great that banks and other business industries should implement it as soon as possible.

For performance improvement, banks need to provide the element of quality service by fulfilling the needs of customers. An empirical study by Osman et al. (2016) define service quality as what customer going to receive from what they are willing to pay for instead of what supplier enclosed. Regardless what type of customers, banks have the obligation to fulfil customers' financial needs by providing quality service consistently or additional services. Khan and Fasih (2014) specifically for the banking business, additional or premium service quality act as a crucial role for customers to assess the performance of the bank and it is a critical point of customer satisfaction and loyalty. 
The important issue of this conceptual paper is the contribution of service quality put forward to customers by the bank for the purpose of customer retention. Service quality, no matter how great the product and the benefits or how influential the seller, one of the matters that customers are most likely to remember is the direct communication they have with the firm, where human interaction plays a crucial part. As long as quality service provided exceeds customers' expectations, customers will be satisfied, and this led to the intention of repeat purchase. As such, Syaqirah and Faizurrahman (2014) the consequence on assessment of service quality can be proven when a firm providing excellent quality service can leads to customers' satisfaction and thereafter customer retention with higher profitability.

Revenue is generated through service quality where profit is concerned, and it is from retained customers. However, complaints cannot be avoided, and the management should handle the complaints process with care. The application of service recovery must be applied by the banks. During the service recovery process banks management collects additional information to be analysed and, fix the root cause to avoid re-occurrence. All the information collected will be utilized for future marketing purposes. Notwithstanding the above, management should investigate further if even service quality with premium has been implemented by the bank and each of the employee is giving the quality service and yet the profit still fluctuates, it is time to analyse the operation cost of the bank.

\section{References:}

Aik, N. C., Hassan, M. K., Hassan, T., \& Mohamed, S. (2015). Productivity and Spillover effect of merger and acquisitions in Malaysia. Management Research Review, 38(3), 320-344.

Al-Alak, B. A. (2014). Impact of marketing activities on relationship quality in the Malaysian banking sector. Journal of Retailing and Consumer Services, 21(3), 347-356.

Alnsour, M. S. (2013). How to retain a bank customer: A qualitative study of Jordanian banks relational strategies. International Journal of Marketing Studies, 5(4), 123.

Appannan, S., Doraisamy, B., \& Hui, T. X. (2013). Customer perception on service quality of commercial banks: A Case Study in Penang, Malaysia. Academic Research International, 4(5), 459.

Arokiasamy, A. R. A. (2013). The impact of customer satisfaction on customer loyalty and intentions to switch in the banking sector in Malaysia. The journal of commerce, 5(1), 14-21.

Bose, S., \& Gupta, N. (2013). Customer perception of services based on the SERVQUAL dimensions: A study of Indian commercial banks. Services Marketing Quarterly, 34(1), 49-66.

Chang, C. W., \& Zhang, J. Z. (2016). The effects of channel experiences and direct marketing on customer retention in multichannel settings. Journal of Interactive Marketing, 36, 77-90.

Coussement, K. (2014). Improving customer retention management through cost-sensitive learning. European Journal of Marketing, 48(3/4), 477-495.

Edward, M., \& Sahadev, S. (2011). Role of switching costs in the service quality, perceived value, customer satisfaction and customer retention linkage. Asia Pacific Journal of Marketing and Logistics, 23(3), 327-345.

Hettiarachchy, B. S., \& Samarasinghe, D. S. R. (2016). Influence of Relationship Marketing on Customer Retention in Sri Lankan Banking Industry (13th International Conference on Business Management 2016).

Hundre, S., Kumar, P. R., \& Kumar, G. D. (2013). Customer Retention--Key to Success for Organization: A Case Study of Banking Industry. Research Journal of Agricultural Science, 4.

Hundre, S., Kumar, P. R., \& Kumar, G. D. (2013). Customer Retention--Key to Success for Organization: A Case Study of Banking Industry. Research Journal of Agricultural Science, 4.

Islam, R., Ahmed, S., \& Razak, D. A. (2015). Identifying the gaps between customer expectations and perceptions on service quality dimensions of Islamic banks in Malaysia. International Journal of Quality and Service Sciences, 7(4), 424-441. 
Kandampully, J., Zhang, T., \& Bilgihan, A. (2015). Customer loyalty: a review and future directions with a special focus on the hospitality industry. International Journal of Contemporary Hospitality Management, 27(3), 379-414.

Khan, M. M., \& Fasih, M. (2014). Impact of service quality on customer satisfaction and customer loyalty: Evidence from banking sector. Pakistan Journal of Commerce and Social Sciences, 8(2), 331.

Lai, K. Y., Ling, T. P., Eng, T. K., Cheng, L. S., \& Ting, L. F. (2015). Financial Performance of Malaysia Local Banks: During Period of Pre-Merger and Post-Merger. Journal of Economics, Business and Management, 3(9), 826-830.

Lau, M. M., Cheung, R., Lam, A. Y., \& Chu, Y. T. (2013). Measuring service quality in the banking industry: a Hong Kong based study. Contemporary Management Research, 9(3).

Mecha, E. K., Martin, O., \& Ondieki, S. M. (2015). Effectiveness of customer retention strategies: A case of commercial banks, Kenya. International Journal of Business and Management, 10(10), 270.

Noel Yee, Tracy Jun and Jackie Yau, (2013). The Roles of Justice and Customer Satisfaction in Customer Retention: A Lesson from Service Recovery. J Bus Ethics, 114:675-686 DOI 10.1007/s10551-013-1713-3.

Osman, Z., \& Sentosa, I. (2014). Influence of Customer Satisfaction on Service Quality and Customer Loyalty Relationship in Malaysian Commercial Banking Industry.

Osman, Z., Mohamad, L., \& Mohamad, R. K. (2016). An Empirical Study of Direct Relationship of Service Quality, Customer Satisfaction and Bank Image on Customer Loyalty in Malaysian Commercial Banking Industry.

Paul, J., Mittal, A., \& Srivastav, G. (2016). Impact of service quality on customer satisfaction in private and public sector banks. International Journal of Bank Marketing, 34(5), 606-622.

Siu, N. Y. M., Zhang, T. J. F., \& Yau, C. Y. J. (2013). The roles of justice and customer satisfaction in customer retention: A lesson from service recovery. Journal of Business Ethics, 114(4), 675-686.

Syaqirah, Z. N., \& Faizurrahman, Z. P. (2014). Managing customer retention of hotel industry in Malaysia. Procedia-Social and Behavioral Sciences, 130, 379-389.

Tan, L. H., Hamid, S. R., \& Chew, B. C. (2016). Service quality audit based on conceptual gaps model of service quality: a case study of top three largest local bank in Malaysia. International Journal of Productivity and Quality Management, 18(1), 99-115.

Wang, K. Y., Hsu, L. C., \& Chih, W. H. (2014). Retaining customers after service failure recoveries: a contingency model. Managing Service Quality, 24(4), 318-338.

Zeyad, M., \& Ab Wahab, N. (2013). Factors affecting customer loyalty in Islamic banking: Evidence from Malaysian Banks. International Journal of Business and Social Science, 4(7). 


\section{Appendix A}

Table 1, sample of commercial banks of Malaysia in term of profit performance for the past ten years.

\begin{tabular}{cccccccccccc}
\hline No. & Banks & $\mathbf{2 0 0 7}$ & $\mathbf{2 0 0 8}$ & $\mathbf{2 0 0 9}$ & $\mathbf{2 0 1 0}$ & $\mathbf{2 0 1 1}$ & $\mathbf{2 0 1 2}$ & $\mathbf{2 0 1 3}$ & $\mathbf{2 0 1 4}$ & $\mathbf{2 0 1 5}$ & $\mathbf{2 0 1 6}$ \\
\hline 1 & Maybank & $\mathbf{3 , 0 5 1}$ & $\mathbf{2 , 3 7 3}$ & 2,457 & $\mathbf{3 , 5 5 3}$ & $\mathbf{3 , 3 5 8}$ & $\mathbf{4 , 3 0 5}$ & $\mathbf{4 , 8 8 5}$ & 5,903 & 5,834 & 6,422 \\
2 & CIMB & $\mathbf{2 , 7 9 3}$ & $\mathbf{1 , 9 3 0}$ & 2,786 & 3,500 & 4,030 & 4,344 & $\mathbf{4 , 5 4 0}$ & $\mathbf{3 , 1 0 6}$ & $\mathbf{2 , 8 4 9}$ & 3,564 \\
3 & HLBB & .547 & $\mathbf{. 6 9 6}$ & $\mathbf{. 6 5 9}$ & .767 & .807 & 1,247 & 1,450 & 1,590 & $\mathbf{1 , 7 7 5}$ & $\mathbf{1 , 6 0 4}$ \\
4 & Affin & .180 & $\mathbf{. 2 9 9}$ & $\mathbf{. 2 9 5}$ & .346 & .388 & .450 & $\mathbf{. 5 0 8}$ & $\mathbf{. 4 7 6}$ & $\mathbf{. 2 6 1}$ & .351 \\
5 & Alliance & $*$ & $\mathbf{. 3 8 1}$ & $\mathbf{. 2 3 7}$ & $\mathbf{. 1 8 3}$ & .321 & .387 & .507 & $\mathbf{. 5 1 1}$ & $\mathbf{. 4 8 3}$ & $\mathbf{. 4 5 2}$ \\
\hline
\end{tabular}

Note:

1) Figures in 'Italic' indicate the comparison between different bank - lower ranking bank perform better the higher-ranking bank.

2) Figures in bold indicate the individual bank's performance comparing preceding year. 